\title{
Proyectos y prácticas curriculares en la universidad pública: sobre el proceso de revisión curricular vigente en la Facultad de Humanidades y Ciencias de la UNL
}

\author{
Julia Bernik(1), Liliana Rossi (2), \\ Marcelino Maina ${ }^{(3)}$, Silvina Chemes ${ }^{(4)}$
}

(1) Desarrollo Curricular, Facultad de Humanidades y Ciencias, Universidad Nacional del Litoral. bernikjulia@gmail.com

(2) Secretaría Académica, Facultad de Humanidades y Ciencias, Universidad Nacional del Litoral. lrossi@fhuc.unl.edu.ar

(3) Dirección de Enseñanza de Grado, Facultad de Humanidades y Ciencias, Universidad Nacional del Litoral. grado@fhuc.unl.edu.ar

(4) Atención al Estudiante, Facultad de Humanidades y Ciencias, Universidad Nacional del Litoral. estudiante@fhuc.unl.edu.ar
Palabras clave. curriculum universitario revisión curricular . formación profesional . prácticas curriculares

Resumen. El presente artículo socializa una experiencia de trabajo colectivo en torno a las prácticas curriculares en una universidad pública. Pretende expresar lo más cabalmente posible el entramado de voluntades y decisiones políticas que se requieren para gestar mejoras en la formación universitaria. Somos conscientes de que el dinamismo de lo real solo puede mostrarse parcialmente en la lógica de una escritura, por lo que describiremos parte de este proceso. En la primera parte presentamos aspectos centrales de su organización y desarrollo hasta la fecha; y en la segunda parte ofrecemos algunas reflexiones sobre sus avances que, aunque provisorios, denotan consensos construidos, desafíos que se abren y direcciones que van tomándose en pos de potenciar un proyecto curricular académica y socialmente relevante. 
Keywords. universitary curriculum · curricular revision · professional training - curricular practices

Abstract. The present article socialises an experience of a work group on curricular practices at a public university. It pretends to express - as accurate as possible - the general framework of willingness and political desicions that are required to develop improvements in university training. Being aware of the fact that the dynamism of the reality can only be shown parcially in written logic, we will describe part of this process. In the first part, we present the central aspects of its organization and development up to date; in the second part we offer some considerations on their progress in spite of being provisional - they denote constructive agreements, challenges that open up and different ways that are being taken to improve an academic curricular project to make it socially relevant.

El presente escrito procura describir la riqueza sustantiva de una experiencia de trabajo colectivo en torno a las prácticas curriculares, y pretende así expresar lo más cabalmente posible uno, entre otros, de los entramados de voluntades y decisiones políticas que se requieren para gestar mejoras en la formación universitaria. Busca compartir una experiencia en marcha, sus principales avances, sin omitir sus dificultades, pero destacando sobre todo los desafíos que se abren y los compromisos que se van asumiendo.

En mayo del año 2013, el Consejo Directivo de la Facultad creó la Comisión Central de Revisión Curricular y ocho Comisiones de Análisis y Revisión Curricular de Carreras - una por cada carrera de grado existente (Res. CD 131/13) — . De ese modo se institucionalizó un proceso de análisis y reflexión sobre los Planes de Estudios y las prácticas curriculares que dispone un valioso escenario de intercambios colectivos.

Dicho proceso, por un lado, se asienta en la historia de la Facultad de Humanidades y Ciencias (FHUC), en los mandatos fundacionales de sus proyectos 